\title{
Traffic Accident Analysis in Prosses Evidence in Traffic Accidents Based on Act No. 22 of 2009
}

\author{
Rudiana Eka Pramana Putra ${ }^{1}$ and Akhmad Khisni ${ }^{2}$
}

\begin{abstract}
Proof play an important role in the process of examination of the court, the development progress in the field of information technology and telecommunications, also developed the theories and practices of the use of evidence outside of a predetermined in the procedural law in Indonesia The problems of this study are: traffic accident analysis methods in the process of proving the traffic accident under the Act No. 22 of 2009. Obstacles and solutions in traffic accident analysis methods in the process of proving the traffic accident under the Act No. 22 of 2009.

The research approach used adalan normative research. Empirical normative legal research. Data obtained from the study will be analyzed using qualitative methods of normative analysis.

Based on this study, the result that the completion of a traffic accident encountered on the streets and certain times and considered as a routine activity, because over the task of administrative services in the field of vehicle or driver in addition to the public discipline road users is still very low. If there is no presence of members of the Police / Traffic Police physically there is a tendency offense by violating traffic signs. So for the purpose of realizing Kamseltibcar Kudus Resort Police and increased professionalism Police Traffic Accident Analysis required implementation by implementing the handling of traffic accident right scene.

Keywords: Law Enforcement; Criminal Law Advisory; Traffic Accident Analysis Proof of Traffic Accidents.
\end{abstract}

\section{Introduction}

Laws or rules as the rules of life in the community association, meneerminkan actual ideals generally accepted value system in the society. If there is a violation by member masyaralcat then the interests of the injured to be replaced or repaired, regulation must on hold and the offender must be given punitive sanctions, which could be imposed on him by the board of public power.

The strength of the evidence against the court ruling in resolving the criminal case is very important for anyone who finished the criminal case. The strength of the evidence is very helpful for investigator in investigating a criminal case because of the absence of evidence, a case can not be resolved shortly. In contrast with the strength of the evidence, the investigators will examine the criminal case in detail and clearly.

The proof play an important role in the process of examination of the court. Proof that determine the guilt or innocence of a person who filed in court. If the result of

\footnotetext{
${ }^{1}$ Student of Master of Law, Universitas Islam Sultan Agung Semarang and Members of the Indonesian National Police (Polri), Email: rudianaekapramanaputra@gmail.com

${ }^{2}$ Faculty of Law Universitas Islam Sultan Agung
} 
evidence with evidence prescribed by statute is not sufficient to prove the fault of the person will be released from punishment, otherwise if the fault can be proved then convicted and sentenced. Therefore, it should be cautious, careful and mature in assessing and considering the issue of proving particularly traffic accidents. ${ }^{3}$

Each verification either by the police, prosecutors and judges should pay attention to the principle of balance matching between the protection of human dignity and the protection of the interests and public order and should not be oriented to the sheer power because it will make proof do become objective as what is reflected in Act No. 8 of 1981 on Criminal Proceedings. In Act No. 8 of 1981 on Criminal Procedure Code now contains akusatur system (accusatiry procedure) that is different from the HIR that uses inkisitur system that emphasizes recognition.

Kudus police station in this regard through the Highway Patrol Unit (PJR) should make efforts to suppress the prevention of accidents with serious. One effort that can be done is to implement a Traffic Accident Analysis in order to reduce traffic accidents in order to realize the professionalism of the Indonesian National Police, especially the Kudus City and the surrounding region. With more direct on the facts (empirical) that occur in the field for analysis. The pressure in this study are the things experienced by the traffic police in the prevention of traffic accidents.

With the development of advances in information technology and telecommunications, also developed the theories and practices of the use of evidence outside of a predetermined in the procedural law in Indonesia. This of course raises a problem that when the evidence developed at this time has not been recognized by the court to be recognized as valid evidence, meanwhile, the old regulation did not immediately replaced / updated so of course there is no means to accommodate the development of evidence in beyond the existing regulations. Based on the above, hence the title of this research are: Traffic Accident Analysis In Prosses Evidence In Traffic Accidents Based On Act No. 22 of 2009.

The problems of this study, as follows: Method of analysis of traffic accident in the process of proving the traffic accident under the Act No. 22 of 2009. Obstacles and solutions a method of traffic accident analysis in the process of proving the traffic accident under the Act No. 22 of 2009

\section{Research methods}

The case study method (genetic approach) is a research method that seek scientific truth by studying in depth and in a long period of time. ${ }^{4}$

The research approach used in this research is normative research. Normative legal research is empirical legal research regarding the implementation of normative legal

\footnotetext{
3 M Yahya Harahap, 2005, Pembahasan mengenai Penerapan KUHAP Pemeriksaan Sidang Pengadilan, Banding, Kasasi dan Peninjauan Kembali, Sinar Grafika, Jakarta, p. 273

${ }^{4}$ Ibid., p. 186-187
} 
requirements (codification, legislation or contracts) are in action at any particular legal events that occur in the community. ${ }^{5}$

\section{Results and Discussion}

\subsection{Traffic Accident Analysis Methods In The Verification Process of Traffic Accidents Based on Act No. 22 of 2009}

According to Act No. 22 Of 2009 regarding Traffic and Road Transport, Infrastructure Traffic and Transportation is Space Traffic, Terminal, and Equipment Road that include markers, signs, Paraphernalia Gesture Traffic control devices and safety Road Users, an oversight and safeguards road, as well as supporting facilities.

According manuscript Traffic Director, Principal Investigator Traffic on the Analysis of Traffic Accidents in 2004 stated that the analysis of traffic accidents is a series of actions the investigator in the case and in the manner set forth in the law to search for, collect and process the evidence that make light of an incident last of traffic accident. From ranks opened function, the function of the traffic in accordance with the duties, functions and their role in fostering kamtibcar then is a function of the police who stood at the front as a uniformed police storefront and have a full role, either in the task of pre-emptive, preventive well as law enforcement duties. Generally Traffic should be able to display a figure of traffic police on the road in accordance with the motto which is always written in traffic police patrol vehicle door is "Protect and Service". In relation to the issues Implementation of Traffic Accident Analysis in order to reduce the number of traffic accidents, the expected conditions are:

- Handling traffic accident right scene

- Implement handling by the scene of traffic accidents in accordance with the stages that is four (4) model of stages of the investigation at the crime scene (TKP) traffic accidents: Phase orientation (orientation stage), Preparation (preparation stage), Phase Implementation (exsecution stage) and Phase Conclusion (conclution stage). The use of models of the above steps is very important, in addition to simplify and shorten the time of the investigation also avoid any overlapping interests that will have an impact on the process of evidence.

- The application of scientific crime investigation in the matter of investigation of traffic accidents in exploring the causes, both of the human factor, vehicle, road and environment. Disclosure of the traffic accident cases should be based on the technology of the police with the investigation steps directed at scientific evidence (forensic criminalistic).

- Documenting a true all the incidents are known and reported to unity. Cases were reported not only that death, serious injury (not all) or roughly easily handled. Likewise, there is no waiver of hit-and-run case in the data collection and efforts to

\footnotetext{
${ }^{5}$ Abdulkadir Muhammad, Hukum dan Penelitian Hukum, Citra Aditya Bakti, Bandung, 2004, p. 134
} 
disclosure. It is expected that there is no tendency member only resolve cases favorable, regardless of the impact. There is no longer any fear in noted with completion targeted cases (manipulation mode).

- Data traffic accident details and specific existence of uniformity in the inclusion in the book 1 by traffic unit then and able to encapsulate all cases traffic that occurred in the region in detail (among other things: the type of collision, shape, location) and specific (the biggest victims, judging from the age, professions and others). Likewise, the transition to the second book by Chief of Traffic unit there should be certain criteria that are the responsibility or serving officer.

\subsection{Barriers and Solutions On Traffic Accident Analysis Methods In The Verification Process Traffic Accidents Based on Act No. 22 of 2009}

The barrier method of Traffic Accident Analysis In The Process Verification Traffic Accidents Based on Act No. 22 of 2009 that is setting the basic skills of traffic management techniques. so usually misused authority to enforce the law. The lack of traffic tertiban as an everyday phenomenon has been seen as a culture so that the behavior of road users who deviate accepted as a condition that can not be circumvented.

The application of penalties for violation of traffic which is still much lower than the maximum fine as stipulated in the legislation. Tertiban non-traffic as a result of government policy to issue licenses concentration to build public places ${ }^{6}$,

The volume of these vehicles are not directly proportional to the good road infrastructure and so on. Whereby the government and think of it in order to reduce traffic accidents, especially in the city of Makassar. the lack of accurate data in the process of investigation and disciplinary society is still low on the traffic discipline rules.

\section{Closing}

\subsection{Conclution}

- Traffic Accident Analysis Methods In The Verification Process Traffic Accidents Based on Act No. 22 of 2009

Handling traffic accident scene right. Implement handling by the scene of traffic accidents The application of scientific crime investigation in the matter of investigation of traffic accidents in exploring the causes, both of the human factor, vehicle, road and environment. Documenting a true All the incidents are known and reported to unity. Cases were reported not only that death, serious injury (not all) or roughly easily handled. Data traffic accident details and specific presence of

\footnotetext{
${ }^{6}$ Interview with Kasatlantas Kudus Police, December 11, 2018
} 
uniformity in the inclusion of the first book by a traffic unit then and able to encapsulate all cases occurring in the traffic territory in detail

- Barriers and Solutions Anything In Traffic Accident Analysis Methods In The Verification Process Traffic Accidents Based on Act No. 22 of 2009

Barriers Traffic Accident Analysis Method In The Verification Process Traffic Accidents Based on Act No. 22 of 2009 that is setting the basic skills of traffic management techniques. So usually misused authority to enforce the law. The lack of traffic tertiban as an everyday phenomenon has been seen 72 as a culture so that the behavior of road users who deviate accepted as a condition that can not be circumvented. The application of penalties for violation of traffic which is still much lower than the maximum fine as stipulated in the legislation.

\subsection{Suggestion}

Suggestions in this study are as follows:

- It is expected that participation in the effectiveness of law enforcement, in addition to adequate rule of law, good law enforcement and infrastructure that support adequate, because without the participation of the community is the rule of law will not be effective.

- It is expected that in the framework of the implementation of law enforcement in order to increase the level of traffic safety as well as the establishment of lawabiding society.

\section{Bibliography}

\section{Books}

[1] M Yahya Harahap, 2005, Pembahasan mengenai Penerapan KUHAP Pemeriksaan Sidang Pengadilan, Banding, Kasasi dan Peninjauan Kembali, Sinar Grafika, Jakarta

[2] Abdulkadir Muhammad, 2004, Hukum dan Penelitian Hukum, Citra Aditya Bakti, Bandung,

[3] Soerjono Soekanto, 2006, Penelitian Hukum Normatif, PT Raja Grafindo Peresada, Jakarta,

[4] Lilik Mulyadi. 2007. Hukum Acara Pidana Normatif, Teoritis, Praktik dan Permasalahannya. Bandung. Alumni

[5] Luhut MP Pangaribuan. 2005. Hukum Acara Pidana: Surat-surat Resmi di Pengadilan oleh Advocat. Djambatan. Jakarta

[6] Moeljatno, Asas-asas 1983 Hukum Pidana, Rineka Cipta, Jakarta,

[7] M. Yahya Harahap. 2008. Pembahasan Permasalahan dan Penerapan KUHAP: Pemeriksaan Sidang Pengadilan, Banding, Kasasi, dan Peninjauan Kembali. Edisi Kedua. Jakarta. Sinar Grafika.

\section{Legislation}


[1] Constitution of the Republic of Indonesia of 1945

[2] Act No. 2 of 2002 on the Indonesian National Police

[3] Act No. 22 of 2009 regarding Traffic and Road Transportation

[4] Wetboek van Strafrecht (WVS) of the Code of Penal (Penal Code)

[5] Act No. 8 of 1981 on the Criminal Procedure Law (Criminal Code)

[6] Police Regulation No. 15 of 2013 on Procedures for Handling Traffic Accidents

[7] Police Regulation No. 10 of 2012 on Traffic Management and Use of Certain Circumstances In addition to Road Traffic To Event

[8] Standard Operating Procedure Handling Traffic 